\title{
A védőügyvédi tevékenység gyakorlásának személyi és szervezeti keretei Magyarországon
}

\author{
Védőügyvéd - szakvizsga - specializáció - ügyvédi kamara - \\ eltérő tagállami modellek
}

Az ügyvédi kar képzési rendszerét szintén számos kritika érte az elmúlt időszakban. Magam is úgy vélem, hogy a hiányosságok elsősorban jogalkotói hibák, illetőleg mulasztások eredményeképpen keletkeztek, mivel sem a büntetőeljárásról szóló 1998. évi XIX. törvény (a továbbiakban: Be.), sem pedig az ügyvédekről szóló 1998. évi IX. törvény (a továbbiakban: Ütv.) nem határolja be pontosan a büntetőügyekben eljárható ügyvédek körét. Márpedig szükség lenne további speciális követelményekre. Jelenleg azonban bármely jogi szakvizsgával rendelkező kolléga megbízható, illetőleg kirendelhető annak ellenére, hogy a napi rutin tekintetében jelentős különbségek mutatkoznak. Ez pedig nyilvánvalóan diszkriminatív helyzetet eredményez a terheltek között, akiknek joguk volna az azonosan hatékony védekezéshez - már csak az Alaptörvény szellemiségéből fakadóan is.

Ami a gyakorlati képzést illeti, az jelenleg szintén meglehetősen szegényesnek bizonyul, hiszen mindössze két pillérre támaszkodik: 1. a kötelezően előírt jelölti oktatásra (ahol tapasztalataim szerint alig kerülnek szóba büntetőjogi praxissal kapcsolatos kérdések), illetöleg 2. a principálisnál eltöltött gyakorlati időre (ami viszont egyáltalán nem kontrollálható). Nincs tehát általános büntető szakirányú „vizsgakényszer" azok számára, akik kizárólag büntetőügyekkel kívánnak foglalkozni. Ehelyett le kell tenni egy olyan, egységesnek nevezett szakvizsgát, ahol a vizsgázónak - teljességgel irracionális módon - „tucatnyi” jogág szabályainak és gyakorlati alkalmazásának ismeretéről kell számot adnia, ráadásul a vizsgabizottság tagjainak személye teljességgel esetleges, kijelölésük során - a büntető szakirányban való jártasságon túl (I. ügyész, védőügyvéd, bíró) - semmiféle személyi kvalifikáció nincs a tekintetben, hogy a vizsgázó milyen jellegü tevékenységet folytatott a jogi diploma megszerzését követő gyakorlati ideje alatt. Egy ügyvédjelölt vizsgázó esetében ugyanakkor értelemszerüen azt tartanám logikusnak, ha a bizottság valamennyi tagja többéves praxissal rendelkező védőügyvéd lenne. Csak az ilyen vizsgáztató tud például az ügyvédi meghatalmazással vagy éppenséggel a bünügyi tényvázlat összeállításával kapcsolatos adekvát kérdéseket feltenni. A vizsgának nem lenne szabad a törvények grammatikai értelmezésére szorítkoznia, márpedig megítélésem szerint legtöbbször ez a tendencia érvényesül.

Dr. Bérces Viktor ügyvéd, megbízott elöadó, PPKE JÁK, Büntetőjogi Tanszék, Budapest, viktor.berces@ gmail.com. 


\section{Szabályozási javaslatok a képzési rendszer átalakítására}

A védőügyvédek megfelelő képzési rendszere olvasatomban egy kétlépcsős jogszabályi reform eredményeképpen alakulhatna ki: 1. meg kellene szüntetni az egységes szakvizsgarendszert, tehát külön kellene választani a ügyvédi, a bírói, az ügyészi, a közjegyzői, illetőleg a közigazgatási szakvizsgát; 2. az ügyvédi szakvizsga előtt állók vonatkozásában kötelezően, de az adott jogterület tekintetében választható jelleggel elő kellene írni a specializációt; 3. az így esetlegesen kiválasztott büntetőjogi szakvizsga - védőügyvédekből álló szakvizsgabizottság előtti - szóbeli abszolválása kizárólagos jogosultságot teremtene a „védőügyvédi”, avagy „bünügyi védői" cím viselésére.

Ami az 1. pontot illeti: az ügyvédi, ügyészi, illetőleg bírói szakvizsgák szétválasztása azért lenne szükséges, mert tudvalevő, hogy az ügyvédjelöltek jelentős része olyan jogi munkát végez, amely nagymértékben különbözik a felsoroltaktól, ezért gyakorlatilag nem hozható létre semmiféle szintézis a vizsgakövetelmények vonatkozásában. A jogi pályák különbözősége folytán tarthatatlan az a helyzet, amelyben a szakvizsgázónak hihetetlen mennyiségben kell számára teljességgel indifferens joganyagot elsajátítani (pl. közjegyzőjelöltek büntetés-végrehajtási jogot), miközben a választott pályájuk szempontjából fontos matériák kimaradnak (pl. ügyészeknél a kriminalisztika). Az elméleti és gyakorlati felkészítés pedig szinte annyiféle, ahány jogi pálya van, és ez a vizsgázó helyzetét rendkívüli módon megnehezíti. ${ }^{1}$

Ami a 2. pontot - tehát az ügyvédi szakvizsgán belüli további differenciálást - illeti, annak egyértelmü előnye, hogy az ügyfelek előtt is egyértelműsítené az ügyvédi specializációt. Az a helyes és kívánatos elvárás, ha a laikus szférából az ügyvédi irodába érkező személy (leendő terhelt, sértett, magánfél, egyéb érdekelt, illetőleg felperes, alperes stb.) tisztában van azzal, hogy melyik ügyvéd milyen tevékenységet folytat. Nézzük logikusan: ha valakinek fáj a torka, akkor nem az ambulanciára megy, hanem a háziorvosához. Ennek analógiájára az ügyvédi praxis tökéletes kikristályosodását jelentené az is, ha az ügyvéd neve után kötelező jelleggel fel lenne tüntetve, hogy „,bünügyi védő”, ,jogi képviselő” vagy éppen „adótanácsadó”. ${ }^{2}$ Nézetem szerint tarthatatlan az a jelenlegi állapot, amelyben minden ügyvéd szinte minden jogággal foglalkozik!

Ami a nemzetközi tapasztalatokat illeti, úgy vélem, hogy az általam alább felsorolt szabályozási modellek „egytől egyig” példaértékűek lehetnek a magyar jogalkotás számára.

a) Németországban és Ausztriában valóban létezik a magyar rendszerhez hasonló, ún. egységes jogi szakvizsga, de a magyar gyakorlattól ott is lényegesen eltér a vizsgát megelőző felkészülési időszak. Jelen szisztémákban ugyanis kizárják a vizsga egységességét, tekintettel arra, hogy az azt megelőző gyakorlat sem egységes.

Vö. BÁNÁTı János: Ügyvédjelöltképzés, jogi szakvizsga, Magyar Jog, 2005/9, 517.

2 Bárándy Péter is hasonló megállapításra jutott a szekszárdi II. Kriminológiai Vándorgyűlésen a „Hatékony védelem követelménye és a büntető eljárásjog reformja" című előadásában. Mondanivalójának esszenciája, hogy a bűnügyi védő nemcsak felkészültségében, de a többi büntető eljárásjogi szereplőhöz hasonló előzetes ellenőrzöttségben is legyen speciális az ügyvédek körében. In: TuRı András: Növekvő bünözés - Új bünözési dilemmák. In: Büntető Eljárásjogi Olvasókönyv, szerk. Tóth Mihály, Budapest, Osiris, 2003, 322. 
Ennek megfelelően ezekben az államokban az egyetem elvégzését követően elöre meghatározott időt kell különböző bírósági ügyszakokban, ügyészségen, közigazgatásban és ügyvédjelölti munkakörben dolgozni, majd csak ezt követheti az egységes jogi szakvizsga.

b) Franciaországban a diploma megszerzését követően el kell végezni egy bizonyos ügyvédjelölti elöképző intézetet, s csak ezután kell kétéves időtartamban ügyvédjelölti szakmai gyakorlatot folytatni. Aki pedig nem tud jelen intézetbe bejutni, annál a szükséges ügyvédjelölti gyakorlati idő nyolc év (!).

c) Olaszországban a kétéves kötelező ügyvédjelölti gyakorlat elött nincsenek ügyvédképző intézeti előtanulmányok, de szigorúan előírák a jelölt által szemeszterenként igazolandó bírósági tárgyalások számát. Mindez biztosítja annak lehetőségét, hogy a vizsgázó a szakvizsga idejére rendelkezzen valamiféle általános ügyviteli ismerettel.

d) Angliában a szintén kétéves ügyvédjelölti képzés csak a Law Society által erre feljogosított ügyvédi irodákban tölthető el, ahol különböző jogterületeken való gyakorlati munkalehetőséget kell biztosítani. ${ }^{3}$

Mindezek alapján a megoldást a jogi szakvizsga több szinten megvalósuló differenciálásában látom, tehát a teljesen különálló ügyvédi szakvizsgán belül is különválasztanám a büntetőjogi, a polgári jogi és a közjogi jellegű szakvizsgákat. Bármelyikük teljesítése pedig önmagában jogalapot teremtene ahhoz, hogy az adott (szektorspecifikus) ügyekben praktizálni lehessen.

Jóllehet, az egységes jogi szakvizsga sokat hangoztatott (ugyanakkor álláspontom szerint egyetlen) előnye, hogy lehetővé teszi a jogászi pályák „átjárhatóságát”, az ún. „szakmai mobilitás” érvényesülését. Ez azonban büntetőjogi területen csakis a bírák és az ügyészek részéről igaz. Egy bíró vagy egy ügyész előtt semmilyen akadály nincs abban a vonatkozásban, hogy szolgálati jogviszonyát megszüntetve ügyvédi irodát nyisson. Sőt meggyőződésem, hogy az ügyvédi kamarák többsége még egyenesen megtiszteltetésnek is veszi azt, ha egy állami szférából érkező jogászkolléga tagfelvételi kérelmet nyújt be. Ezzel szemben, ha egy ügyvéd kíván a továbbiakban bírói vagy ügyészi tevékenységet folytatni, akkor - annak ellenére, hogy erre törvényi lehetősége van - azzal a trenddel kell szembesülnie, hogy a kinevezéseknél egyértelműen előnyben részesítik a fogalmazói, avagy titkári pozícióra épülő karriermodellt.

Az ügyvédi szakvizsga további differenciálásával szemben felmerülhet az a „rosszmájú” kérdés is, hogy „Valójában milyen ügyvéd az, aki még egy keresetlevelet sem

${ }^{3}$ „Az Igazságügyi Minisztérium, a Magyar Jogász Egylet mellett az Ügyvédi Kamarák is felismerték, hogy a jogászképzés területén kritikus helyzet alakult ki. Ügyvédi szemmel nézve nemcsak az egyetemi jogászképzés helyzete kritikus, hanem alapvető problémák mutatkoznak a jogi szakvizsgát kötelezően megelőző hároméves joggyakorlattal és magával a szakvizsgával szemben is. Elsősorban nem ügyvédi problémáról, hanem össztársadalmi kihatású kérdésröl van szó. Az ügyvédi létszám az elmúlt években beindult és a közeljövőben várhatóan még növekvő ütemű emelkedése önmagában nem tudja biztosítani az ügyvédi munka minőségének emelkedését, azaz a társadalom érdekével is ellentétes, hogy mennyiségileg ugyan több, de minőségileg képzetlenebb ügyvéd álljon a jogkeresők rendelkezésére. Az alulképzett és adott esetben egzisztenciális gondokkal is küszködő (az etikai szabályokat nem ismerő, ill. azokat könnyebben háttérbe szorító) ügyvéd saját pályáján túl veszélyezteti az igazságszolgáltatást és a hozzá forduló ügyfeleket." BÁNÁTI: i. m., 516. 
tud megírni?" Nem hathat ez a szisztéma a szakmai igénytelenség irányába? Úgy gondolom, hogy pont ellenkezőleg: végre mindenki azzal foglalkozna, ami már az egyetemen is érdekelte, amivel jelöltként foglalkozott, illetöleg amilyen ügytípus a személyiségével összeegyeztethető. Ez a javaslat persze nem zárja ki azt, hogy egy már büntetőjogi védelem ellátására jogosult ügyvéd a későbbiekben polgári vagy közigazgatási jogi szakvizsgát is letegyen, de e három jogterület teljes gyakorlati szintű elsajátításának követelménye felesleges terhet ró a leendő kollégák számára.

A jogi reformok során mindazonáltal azt kell szem előtt tartani, hogy a vizsgázótól nem várható el, hogy a bírói gyakorlatot ismerve, konkrét jogesetek kapcsán, tárgyilagosan nyilatkozzék olyan jogi kérdésekben, amelyekkel az egyetem elvégzése óta nem foglalkozott. Egy polgári ügyszakban ítélkező bírótól sem várható el az, hogy egyik nap házassági bontóperben, másik nap pedig büntetőügyben ítélkezzen. Javaslatom tehát az Ütv.-ben módosítandó jogi passzusra: „büntetőjogi védelmet az láthat el, aki büntetőjogi szakvizsgával rendelkezik”. Ugyanígy: „polgári ügyekben jogi képviseletet az láthat el, aki polgári jogi szakvizsgával rendelkezik", stb.

Jelen gondolatmenetet egyáltalán nem érzem utópisztikusnak, ugyanakkor időszerünek sem. Utóbbinak azért nem, mert tudvalevőleg jogászi túlképzés folyik. A „kezdő lökést” a jogalkotónak kell megadnia a jogászképzés mennyiségi mutatóinak racionalizálásával. Ezután következhetnének az ügyvédi törvény módosításával kapcsolatos egyéb országgyűlési teendők (természetesen az országos, illetőleg különböző területi ügyvédi kamarák állásfoglalásainak beszerzésével), végezetül magára az ügyvédi kamarákra vár az effektív specializáció irányába ható elméleti és gyakorlati képzések megtervezése és lebonyolítása. A jogszabályi módosítások keresztülvitele természetesen jelen esetben is csak hosszú távon lehetséges.

\section{Az alkalmazott ügyvédek tevékenységének megítélése}

Az Ütv. 84. § (1) bek. alapján alkalmazott ügyvéd az, aki tevékenységét ügyvéddel, illetve ügyvédi irodával létrejött munkaviszony alapján végzi. E reláció joghatása a törvény szerint abban áll, hogy az alkalmazott ügyvéd egyáltalán nem járhat el önállóan az Ütv. által nevesített tevékenységek tekintetében, így bűnügyi védői minőségben sem. Ez az önállótlanság pedig azt fejezi ki, hogy csakis az őt alkalmazó ügyvéd felelösségi körén belül, és utasításai alapján müködhet közre.

Az alkalmazott ügyvéd kizárólag a munkáltatója részére adott megbízás és kirendelés keretei között végezheti tevékenységét, és csak a munkáltatója egyetértésével helyettesíthet más ügyvédet [84. § (2) bek.]. Ennek megfelelően kizárólag egy ügyvéddel, illetve ügyvédi irodával állhat munkaviszonyban [86. § (1) bek.]. Garanciális szabályként kell értékelni, hogy a munkáltató felelősségbiztosítása az alkalmazott ügyvéd tevékenységére is kiterjed [86. § (3) bek.].

Magam is fontosnak vélem, hogy az alkalmazott ügyvédnek ne lehessen saját személyes ügyfélköre, kivéve a jogi segítségnyújtásból, illetőleg az iroda megbízásából fakadókat. ${ }^{4}$ Egyetértek azzal a nézőponttal is, melynek alapján a munkáltató

4 Dobrossy István hozzászólása az Ütv. módosításához, http://debreceniugyvedikamara.hu/request.php?9. 
ügyvédnek bizonyos garanciákat kellene biztosítania az alkalmazott ügyvédnek a munkaszerződések megkötése során, így jogot a folyamatos képzéshez, illetöleg jogot arra, hogy lelkiismereti okokra hivatkozva bizonyos feladatok elvégzése alól felmentést kérhessen. A szerződésnek nem lenne szabad tartalmaznia olyan záradékokat sem, mint például a felmondás szabályozása a kötelező szabályoktól eltérő módon, vagy a munkavállaló későbbi tevékenységének korlátozásával kapcsolatos elöírások stb. Ezen túlmenően, az alkalmazott ügyvéd számára elegendő időt kellene biztosítani ahhoz, hogy a képzésének valamennyi óráján részt vehessen, mindezt a megfelelő szakosodás érdekében. ${ }^{5}$ Ezeket a normákat álláspontom szerint az Ütv.ben kellene lefektetni.

A Magyar Ügyvédi Kamara 3/1999. (V. 3.) számú állásfoglalása szerint az alkalmazott ügyvéd tevékenysége a hatóságok és harmadik személyek viszonylatában képviseleti tevékenységként jelentkezik, és ezen nem változtat az a körülmény sem, hogy a megbízást a munkáltatójának adott alapmegbízás tartalma szerint teljesíti. Az alkalmazott ügyvéd tehát - tevékenysége tartalmát tekintve - ügyvédi tevékenységet folytat. E tevékenység ugyanazon garanciák meglétét feltételezi, mint amelyeket általában az ügyvédi hivatást gyakorlóknál alappal látunk szükségesnek. Az ügyféllel való kapcsolatában - az anyagi felelősségtöl eltekintve - az érdemi tevékenység tartalmát illetően jelentős különbség nincs. Jogi helyzetének sajátosságai föképpen a munkaadójával és a kamarával való kapcsolatában mutatkoznak meg. ${ }^{6} \mathrm{Az}$ alkalmazott ügyvéd ugyanakkor az ügyvédi eskü letétele után csak formai értelemben válik jogosulttá az ügyvédi hivatás gyakorlására. Mindez azonban nem teszi lehetövé számára az önálló ügyvállalást, a megbízási szerződések önálló megkötését, és egyáltalában nem tanúsíthat olyan magatartást, amely külső szemlélő számára az önálló ügyvédi minőség benyomását keltheti.

\section{Az ügyvédjelöltek eljárásával és képzésével kapcsolatos megjegyzések}

Az ügyvédjelölt a büntetőeljárás során a nyomozati, illetőleg a vádszakasz teljes egészében, a bírósági szakban pedig a helyi bíróságok előtti eljárásokban járhat el védőként, ügyvéd mellett vagy ügyvéd helyetteseként [l. Be. 44. § (5) bek.]. E megszorítónak tünő szabály ellenére azonban - némileg furcsának tűnő módon - már csak elvi okokból is aggályosnak érzem azt, hogy az ügyvédjelöltek önállóan eljárhatnak a büntetőeljárásban. Úgy vélem, hogy a terhelti érdekekre figyelemmel az lenne a helyes, jogállami mércének megfelelő szabályozás, ha a jelöltek eljárási cselekményeken történő részvételére csakis ügyvédi jelenlét mellett kerülhetne sor (utóbbi személynek természetesen nem kellene feltétlenül egyben a jelölt principálisának is lennie).

Ami az ügyvédjelöltek képzési rendszerét illeti, az nézetem szerint két okból is problémás. Egyrészt kontrollálhatatlan a principális tevékenysége, emiatt egyáltalán nem tartanám elképzelhetetlen megoldásnak a jelölteket foglalkoztató ügyvédek ese-

5 Uo.

6 http://www.miskolciugyvedikamara.hu/index.php?menu=8\&id=15. 
tében, hogy az Ütv. által kötelezve legyenek a legalapvetőbb ügyvédi feladatkörökkel kapcsolatos ismeretanyag általános oktatására (I. okiratszerkesztés, polgári, illetőleg büntetőbíróság tárgyalásán történő részvétel, az ügyvédi letétkezelésre vonatkozó eljárás megismertetése, stb.), mindezt pedig a MÜK által elöre meghatározott „sablon” szerint végezhetnék. A principálisi oktatást aztán a területileg illetékes kamara által szervezett központi vizsga zárhatná. Ezt elősegítendő szükséges volna az alábbi törvénymódosítás is: „ügyvédjelöltet az az ügyvéd, avagy ügyvédi iroda alkalmazhat, amely vállalja a MÜK által az adott tárgyévre vonatkozó gyakorlati felkészítést, az ott meghatározott módon és feltételekkel".

Persze jelen szisztémával kapcsolatban felmerül a kérdés: ezek után ugyan ki alkalmazna jelöltet, pláne úgy, hogy annak „alkalmasint” még munkabért is „illik” fizetni? Erre nem tudok megnyugtató választ adni, mert feltehetőleg drasztikusan csökkenne a jelöltet alkalmazó praxisok száma. De hát mit veszíthetünk ezzel? Tisztában vagyunk a piaci viszonyokkal, és úgy vélem, nem lenne helyes, ha az ügyvédi irodák továbbra is az első számú „munkaerő-felvevő gépezet” képében tetszelegnének. $^{7}$

Végezetül: úgy gondolom, hogy a szakmai felkészítést mindenképpen meg kellene osztani a principális és a kamara között, melyben elöbbinek inkább a pálya ,jogon kívüli faktorait" kellene érintenie (pl. retorikai, pszichológiai, általános ügyviteli kérdéseket), míg utóbbinak - a bíróképző akadémiák mintájára - a tételes jogi rendelkezések, valamint a bírósági gyakorlat oktatására kellene összpontosítania.

\section{A kamarai rendszer mint az ügyvédi tevékenység gyakorlásának szerve- zeti kerete}

Az ügyvédi praxis egy speciális köztestületi forma, valamely ügyvédi kamara tagjaként folytatható. Mindez azonban csak igazgatási jellegủ hierarchiát teremt az ügyvéd és a kamarák között, s ebbe a „mérsékelt függőségi viszonyba” még álláspontom szerint „belefér” a fegyelmi szankcionálás lehetősége is. Az ügyvéd azonban szakmai értelemben teljes függetlenséget élvez.

Az ügyvédi kamarák rendeltetése elsősorban az ügyvédség szakmai továbbképzésében és érdekképviseletében rejlik, ugyanakkor véleményt nyilvánítanak az ügyvédi tevékenységgel kapcsolatos jogalkotási kérdésekben, döntenek az ügyvédek kamarai tagságának keletkezéséről és megszúnéséről, valamint - adminisztratív jelleggel - vezetik az alkalmazott ügyvédek, alkalmazott európai közösségi jogászok,

7 A principális által elvégzendő érdemi oktatásra azért is szükség van, mert a kamarák által szervezett kurzusok óraszámát - elsősorban a jelöltek munkaidő-beosztásai közötti jelentős eltérések miatt - nem lehet megemelni (személyes tapasztalataim alapján tulajdonképpen havi 1 alkalom, ami átlagosan megtartható). Ezenkívül némely megyében megelégszenek az éppen aktuális jogszabály-módosítások felvázolásával, másutt pedig valós, komoly gyakorlati felkészítés zajlik, a foglalkozásokon katalógust tartanak, a hiányzásokat számon tartják stb. Általános probléma az is, hogy a legtöbb kamara által szervezett oktatási program elsősorban a polgári ügyekben való jogi képviselet gyakorlati megközelítésére fókuszál, illetőleg a jelöltek érdeklődésétől teszi függővé a foglalkozások anyagát. 
az ügyvédjelöltek, az európai közösségi jogászok, a külföldi jogi tanácsadók és az ügyvédi irodák névjegyzékét.

Némileg magam is aggályosnak vélem, hogy az ügyvédi kamarákon belül nincs külön tagozat a büntetőjogi védelmet (is) ellátó kollégák számára, mint ahogy intézményesített specializáció sincs. A kamarák ugyanakkor névjegyzéket vezetnek a védőként kirendelhető ügyvédekről, a kirendelő hatóság pedig ezen listából választ. ${ }^{8}$ A kamarák többféle módszert alkalmaznak ennek összeállításánál: 1. külön megjelölik azoknak a nevét, akik kifejezetten kérik, hogy számukra a hatóság biztosítson kirendeléseket vagy 2. önkéntes jelentkezés alapján állítják össze azokat. ${ }^{9}$

Az Ütv. taxatíve felsorolja a kamarai tagsági jogviszony létesítésének feltételeit, amelyek teljesülése esetén a tagfelvétel nem tagadható meg. A magyar szabályozás tehát meglehetősen nagyvonalúan kezeli az ügyvédi pályára való alkalmasság kérdését, ugyanakkor a magam részéröl szükségesnek tartanám például azt, hogy az ügyvédi, illetőleg ügyvédjelölti felvételkor készüljön orvosszakértői vélemény a kérelmező szellemi és fizikai állapotáról. Ebből a szempontból érdemes lenne megfontolni a német ügyvédi törvény 9 . §-ának az Ütv.-be történő beépítését, amely az ilyen jellegű dokumentum beszerzését kötelezővé teszi. ${ }^{10}$

A tagfelvételek szabályozásával kapcsolatban megjegyezném: európai tendencia, hogy az adott állam valamely kamarájába történő felvétel az összes többi kamara vonatkozásában is érvényes (így az ügyvéd mentesül azon pluszkötelezettségek alól, amelyeket egy esetleges átjelentkezés esetében kellene teljesítenie). Ennek értelmében, ha egy magyar állampolgár bármely ügyvédi kamara által elöírt feltételeket teljesíti, és Magyarország területén valamelyik ügyvédi kamarába felvételt nyert, azt úgy kell tekinteni, mintha minden egyéb, Magyarország területén lévő kamara által elöírt feltételeket teljesítette volna. Ugyanígy a német ügyvédi törvény 5 . §-a kimondja, hogy amennyiben egy ügyvéd valamelyik kamarába felvételt nyert, akkor azt úgy kell tekinteni, hogy teljesítette a Németország területén lévő valamennyi kamara által elöírt feltételeket.

Ehhez képest némi korlátozást jelent az Ütv. azon szabálya, amelynek értelmében az ügyvéd Magyarországon egy kamara tagja lehet, és ennek a kamarának a területén tarthat fenn irodát és alirodát [19. § (1) bek.]. Ugyanilyen területi jellegü korlátozást jelenít meg a német ügyvédi törvény 27 . §-a, amelynek alapján az ügyvéd köteles valamely bírósághoz belépni, és ennek az illetékességi területén köteles egyben ügyvédi irodát is nyitni. Az osztrák ügyvédi törvény 7/A. §-a ezzel szemben úgy rendelkezik, hogy az osztrák ún. „ügyvédi társaság” telephelyet létesíthet (tekintettel arra, hogy Ausztriában a polgári jog szabályai szerinti társaság hozható létre ügyvédi tevékenység létesítésére, amelynek székhelye és telephelye van). Amenynyiben a telephely más ügyvédi kamara müködési területén fekszik, mint amelyikbe

8 Az Ütv. nem tartalmaz irányadó szabályokat a jegyzék összeállítására, csupán annyi kötelezettséget állapít meg, hogy annak biztosítania kell a büntetőeljárás zavartalan működését.

9 KÁDÁR András Kristóf-Tóth Balázs-VAVRó István: Védtelenül. Javaslat a magyar kirendelt védői rendszer reformjára. http://helsinki.hu/dokumentum/Vedtelenul.pdf.

10 Dobrossy: i. m. 
az ügyvédi társaság bejegyzésre került, abban az esetben a telephely szerint illetékes ügyvédi kamarát a telephely létesítéséről meg kell hallgatni. ${ }^{11}$

\section{Szervezeti megoldások Európában}

Az európai államok szabályozási rendszereit összevetve megállapítható, hogy mindenütt található valamilyen szakmai szervezet (pl. ügyvédi kamara, jogászegyesület stb.), amely az ügyvédi tevékenységet irányítja. A legfőbb funkciók természetesen a szakmai-etikai alapú normák meghatározásához, illetöleg a fegyelmi jogkör gyakorlásához kapcsolódnak.

a) Anglia és Wales esetében mindenekelőtt ketté kell választanunk a tárgyalóügyvédi feladatokat ellátó „barrister” és a jogtanácsosi funkciót ellátó „solicitor” fogalmát. ${ }^{12} \mathrm{~A}$ barristerek irányítószerve a tárgyalóügyvédi kamara, amelyet elsősorban a hivatás normáinak és függetlenségének megőrzése érdekében hoztak létre. A solicitorok esetében a jogászegylet (Law Society) lát el képviseleti feladatokat, melynek során e testület állandó kapcsolatban áll a kormányzattal, illetőleg lobbitevékenységet, valamint különböző szakmai jellegü képzéseket folytat.

b) Franciaországban az ügyvédek a megyei bíróságok mellett létrehozott, 183 anyaországi és tengerentúli kamarához tartoznak. A legfőbb szerv az Ügyvédi Kamarák Országos Tanácsa (Conseil National des Barreaux; CNB), amelynek feladata, hogy ellássa az ügyvédi hivatásrend hatóságok előtti képviseletét, és felügyelje a szakma alapvető szabályainak összehangolását. Érdekességképpen megjegyzendő, hogy az Államtanács és a Semmítőszék ügyvédei külön szakmát alkotnak. Mindezt jól jelzi, hogy kizárólag ők biztosíthatják a legfelsőbb bíróságok előtti képviseletet, amikor az kötelező.

c) A Németországban praktizáló ügyvédek kötelező jelleggel tagjai valamelyik tartományi kamarának, tevékenységüket pedig a szövetségi rendtartás (Bundesrechtsanwaltsordnung) rendelkezései alapján végzik. A tartományi kamarák egyesületi szabályzataikban határozzák meg az alapvető ügyvédi feladatokat, ilyennek tekinthető többek között az ügyvédek szakmai magatartási kódexe (Berufsordnung der Rechtsanwälte). A szövetségi ügyvédek hivatalos jegyzékét a Szövetségi Ügyvédi Kamara vezeti, amelyben valamennyi ügyvéd fel van tüntetve. Emellett a Német Ügyvédi Egyesület (DAV) tekinthető az ügyvédek legnagyobb egyesületének, amely széles körben nyújt tájékoztatást az ügyvédi hivatásról - többek között a szövetségi ügyvédi tájékoztató szolgálat keretében.

d) Ausztriában az ügyvédi hivatás gyakorlásának legfontosabb jogszabályi hátterét az ügyvédi rendtartás (Rechtsanwaltsordnung) adja, ügyvédi kamara (Rechtsanwaltskammer) pedig minden szövetségi tartományban müködik. A regionális

11 Dobrossy: i. m.

12 A „solicitori” hivatásrend viszonylag későn alakul ki ezen államokban, mivel a „barristerek” azt megelőzően mindenféle ügytípussal foglalkoznak. JACKSON, R. M.: The machinery of justice in England, Cambridge, University Press, 1953, 203. 
kamarákat az Osztrák Ügyvédi Kamara (Österreichischer Rechtsanwaltskammertag) fogja össze szövetségi szinten.

e) Portugáliában az ügyvédek (advogados) a kamaránál (Ordem dos Advogados) történő nyilvántartásba vétel után kezdhetik meg tevékenységüket. Utóbbi testület hatásköre kiterjed a szakmai szabályok meghatározására, az ügyvédekkel és jelöltjeikkel szembeni fegyelmi intézkedések meghozatalára, valamint vélemények, illetve jogalkotási javaslatok megfogalmazására a szakma gyakorlásával, illetve általában a jogi képviselettel kapcsolatban. Megjegyzendő, hogy a portugál jogrendszer nem tesz különbséget ügyvédek és jogi tanácsadók között. ${ }^{13}$

\section{Záró gondolatok, az ügyvédi szolgáltatásnyújtás lehetősége és korlátai az Európai Unióban}

Bánáti adatai szerint 1960 és 1990 között a Budapesti Ügyvédi Kamara taglétszáma átlagosan 500-600 között volt, s évente legfeljebb 10 ügyvédjelölt került bejegyzésre. A szerző mindehhez hozzáteszi azt is, hogy a budapesti ügyvédi létszám jelenleg meghaladja az 5000 föt, az ügyvédjelöltek száma ugyanitt kb. 2300 körül van. További probléma Bánáti szerint, hogy az utóbbi 15 évben gyökeresen megváltozott az ügyvédi munka tartalma, amely elsődlegesen a gazdasági jog területéhez kapcsolható tevékenységekhez köthető. Mindez elsősorban a cégeljárással kapcsolatos, illetőleg cégképviseleti jellegű tevékenységekben fejeződik ki. ${ }^{14}$

A honi ügyvédi karnak elöbb-utóbb ugyancsak számolnia kell uniós piaci viszonyokkal is. Az uniós jog nem szabályozza a jogi szakmák gyakorlásának feltételeit, ugyanakkor már egy 1998-as irányelv is rögzíti azokat a kritériumokat, amelyek mentén az egyik tagállamban képesítést szerzett ügyvéd egy másik tagállamban tartós jelleggel gyakorolhatja hivatását. A Tanács 98/5/EGK irányelve szerint a fogadó ország hatóságainak részletesen kell vizsgálniuk az ügyvédségre pályázó jogász képzettségét és tudását, érdemben kell áttekinteniük a külföldi jogi diploma által nyújtott ismereteket. Ehhez még hozzátartozik az is, hogy nem elegendő a fogadó államban megkövetelt diploma hiányára hivatkozni, s erre alapozva elutasító döntést hozni.

Lényeges szabály továbbá, hogy az ügyvéd hazai címét a fogadó ország nyelvére is le kell fordítani, de mindezt oly módon, hogy azt ne lehessen összekeverni a fogadó ország diplomájával rendelkező ügyvédekkel. Szintén jogegyenlőséget biztosító elöírás, hogy a hazai címe alatt müködő ügyvéd munkaviszonyban is elláthatja tevékenységét, azaz egy másik ügyvéd, ügyvédi iroda vagy vállalkozás alkalmazottja is lehet, amennyiben ezt a fogadó ország irányadó jogszabályai az ott honos ügyvédeknek megengedik. ${ }^{15}$

13 https://e-justice.europa.eu/content_legal_professions-29-fr-en.do?clang=hu; https://e-justice.europa.eu/ content_legal_professions-29-de-en.do?clang=hu; https://e-justice.europa.eu/content_legal_professions29-pt-en.do?clang=hu; https://e-justice.europa.eu/content_legal_professions-29-at-en.do?clang=hu.

14 BÁNÁTI: i. m., 516.

15 http://www.euvonal.hu/index.php?op=kerdesvalasz_reszletes\&kerdes_valasz_id=1025. 


\begin{abstract}
In the Hungarian system of criminal procedure, several participants of the proceeding may provide activities aiming at the defence of the defendant (e.g. the prosecutor or even the defendant himself). My dissertation, however, shall focus on the activities of the defender based on delegation or recorded Power of Attorneys given, in consideration of the fact that almost without exception this personal group act as advocates in criminal procedures, furthermore, solely lawyers have the expertise necessary for the defence, and the "equality of arms" principle may only succeed completely through them.
\end{abstract}

